\title{
What Determines China's FDI Inflow to South Asia?
}

\author{
Muhammad Abdul Kamal \\ PhD candidate, School of Economics, Huazhong University of Science and Technology (HUST),Wuhan. P.R. China \\ Email: mak.1947@yahoo.com \\ Professor Zhaohua Li \\ School of Economics, Huazhong University of Science and Technology (HUST), Wuhan. P.R. China \\ Email: zhaohuali@hust.edu.cn

\section{Dr. Ghulam Akhmat} \\ Post-doc Research Fellow, College of Public Administration, \\ Huazhong University of Science and Technology (HUST), Wuhan. P.R. China \\ Email: ahmad_choudary@hotmail.com \\ Malik Fahim Bashir \\ PhD candidate, School of Economics, \\ Huazhong University of Science and Technology (HUST), Wuhan. P.R. China. \\ Email: malik_fhm@yahoo.com \\ Khalid Khan \\ PhD candidate, School of Economics, \\ Huazhong University of Science and Technology (HUST), Wuhan. P.R. China \\ Email: khalidkk82@yahoo.com
}

\section{Doi:10.5901/mjss.2014.v5n23p254}

\section{Abstract}

This study investigates empirically the determinants of China's outward foreign direct investment in South Asia. Our estimation results based on the panel data for five South Asian economies (Bangladesh, India, Nepal, Pakistan and Sri Lanka) over the period 2003 to 2012. POLS method is used for estimation of model after conducting Hausman specification and Lagrangian Multiplier (LM) tests. This paper highlights the findings that macroeconomic variables such as infrastructural facilities, inflation, bilateral trade, market potential and trade openness have significant and positive impact on FDI inflow. Among the institutional variables, level of corruption is highly significant and negatively associated with inflow of Chinese FDI. This empirical study has some policy implications for policy makers. To attract further Chinese FDI, South Asian economies should step forward and opt incremental efforts to remove all trade barriers, reduce corruption and build appropriate institutions. Policies and economic strategies should aim at liberalizing trade structure, reducing macroeconomic instability and provision of better infrastructural facilities to attract further Chinese FDI into South Asia.

Keywords: Foreign direct investment, South Asia, macroeconomic variables, institutional variables

\section{Introduction}

Since the instigation of economic reforms in 1978, China is now emerged and widely recognized as global economic powerhouse. Over the years, inward FDI contributed extensively for remarkable economic achievement and considered as an important parameter in accelerating the process of economic growth and development in China. In contrast, Chinese Outward Foreign Direct investment (OFDI) was generally discouraged and restricted by the central authorities until 2002, when the leadership realized and launched a new strategy to support and encourage Chinese firms to invest abroad. After accession to WTO in 2001 and in pursuit of "Go Globally" strategy, China has consistently been able to 
invest despite of recent year's financial crisis 2008-09. As the world's $3^{\text {rd }}$ largest investor, China is providing momentum to world economic growth by investing in different regions of the world (UNCTAD, 2013). Outward investment from China continues to grow to a record level of $\$ 87.8$ billion in the year 2012 (figure 1), while outward FDI from developed countries fell by $\$ 274$ billion in the same year.

Fig 1: China's OFDI flow, 2000-2012

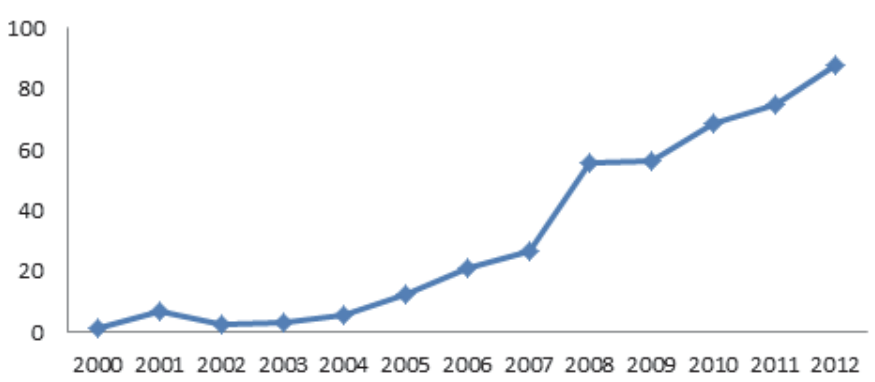

Source: 2012 Statistical Bulletin of China's Outward Foreign Direct Investment.

The rapid and consistent growth in China's outward foreign direct investment has attracted significant attention from policy makers and academics in recent years. It was documented in Untied Nation's annual report (1993) that FDI from developing country provides a new source of skills, technology and capital, hence propagate a positive development. The advantage is associated with South-South FDI in comparison with traditional FDI from developed countries on the argument that technology used by developing nation's FDI is more appropriate (Aykut \& Goldstein, 2007). Further, political turmoil is a consistent phenomena in South Asian countries except India in recent years, while Chinese investment firms have the experience and managerial skills in surviving in adverse governance and political circumstances (Lecraw, 1993). The size and strength of Chinese firms is quite different from traditional firms, therefore, there is less possibility that Chinese firms may crowd out domestic firms (Brautigam, 2009). Chinese firms have some unique characteristics therefore, it is worth studying to find out the determinants of Chinese OFDI in developing countries particularly in South Asian economies.

Table1: Geographical distribution of China's outward FDI flows, 2012

\begin{tabular}{cccc}
\hline Continents & FDI flow (\$billion) & Share (\%) & Year on year growth rate (\%) \\
\hline Asia & 64.785 & 73.8 & 42.4 \\
Europe & 7.035 & 8 & -14.7 \\
Latin America & 6.170 & 7 & -48.30 \\
North America & 4.882 & 5.6 & 96.90 \\
Africa & 2.517 & 2.9 & -.20 .60 \\
Oceania & 2.415 & 2.7 & -27.30 \\
Total & 87.804 & 100 & 17.60 \\
\hline
\end{tabular}

Source: 2012 Statistical Bulletin of China's Outward Foreign Direct Investment.

Since 2003, FDI by Chinese investment firms has pegged up particularly in developing countries. In 2012, China's OFDI to Asia reached $\$ 64.785$ billion accounting for $73.8 \%$ of the total (table 1). China is making substantial investment in all other parts of Asia but meagerly in South Asia. China (including Hong Kong, Taiwan and Macau) supplied only 6\% share in total inward FDI to South Asia during 2003-11 (figure 2). On the other hand, South Asian economies have large savinginvestment gap, unable to create capital which is necessary for economic development, consequently heavily rely on external sources. South Asia with huge market size (24\% of world population) and one of the world's fastest growing region over the period 2000-11 is unable to attract Chinese FDI extensively (World Bank, 2013). One key question is: Why China is reluctant to invest in South Asia or which factors hinder the flow of investment? The possible answer to this question is vital in economics, politics, business, and academia in the region and hence calls for further investigation and analysis of the forces driving Chinese FDI. 
Fig 2: Sources of FDI inflows in South Asia, 2003-2011.

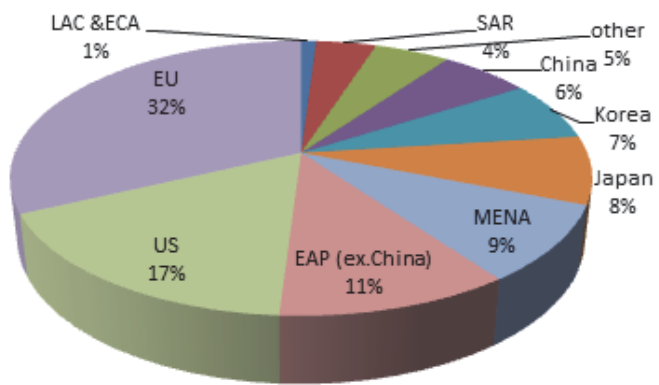

Source: Trends and determinants of foreign direct investment in South Asia: The World Bank Group Report, 2013.

This study contributes to the existing literature in three folds. Firstly, this study explores the factors influencing the location priority of Chinese firms in South Asia considering traditional economic along with institutional factors. Secondly, China is investing extensively in Asia but South Asia's share comparatively to other Asian regions is very meager. This study is carried out to investigate the priorities of Chinese investment firms along with the factors influencing investment adversely. Thirdly, this study aims at examining the factors that influence FDI in South Asia, enabling us to propose some measures and policies to promote and attract more FDI from China in the continent.

We used panel data technique to explore the main drivers of FDI inflows in South Asia for the period 2003-2012. In order to choose proper model, Hausman specification test and Lagrangian Multiplier (LM) test are conducted and their results support pooled OLS estimation method for econometric analysis. The empirical results from the current study reveal that infrastructural facilities, inflation, bilateral trade, market potential and trade openness have positive and statistically significant factors in determining Chinese FDI in South Asian countries. Corruption, the institutional variable has negative and highly statistically significant impact on Chinese FDI. The results have some policy implications for South Asian economies. Incremental efforts at government level are required to remove all trade barriers, reduce the level of corruption and build appropriate institutions. Polices should aim at improving openness to trade and investment, reducing macroeconomic instability and provision of better infrastructural facilities to attract further Chinese FDI in the region.

The remainder of the paper is structured as follows. Section 2 includes brief discussion of previous studies. Section 3 presents rationale for model's variables. Section 4 discusses the data, model specification and econometric methodology. Section 5 contains the main findings of the empirical model, their analyses and assessments and last section offers conclusion of the study.

\section{Literature Review}

\subsection{Conceptual Framework}

A holistic and theoretical frame work for FDI Determinants is the "Eclectic Paradigm" developed by Dunning (1976). It provides a frame work to explain firm behaviors and FDI activities. This approach posits that MNEs invest abroad to take three kind of advantages: Ownership (O), Location (L) and Internalization (I) advantages. Ownership and internalization advantages are associated with firms' specific advantages in manufacturing, distribution, by exploiting imperfections in external markets, cost reduction and provision of subsidies etc. The location advantages are specific advantages that make the chosen host country attractive for investing firms. Dunning's four motivations of FDI (market seeking, efficiency seeking, resource seeking and strategic asset seeking) derived from location advantages are used in previous studies to explore the determinates of Chinese OFDI (Amighini, Rabellotti, \& Sanfilippo, 2011; Buckley et al., 2007; Cheung \& Qian, 2009; Kolstad \& Wiig, 2012; Zhang \& Daly, 2011).

Policy and non-policy factors also acts as driving force of FDI(Fedderke \& Romm, 2006).Policy factors refer to trade barriers, openness, product market regulations, corporate tax and infrastructure, while non-policy factors include distance or geographical location of host country, size of market, factor endowments and political and economic stability (Mateev, 2009)."Push and Pull Factors" are classified and identified as potential determinant or factors that influence FDI 
decisions (Calvo, Leiderman, \& Reinhart, 1996; Fernandez-Arias, 1996; Fernandez-Arias \& Montiel, 1996; Gottschalk, 2001). Push factors are relating to cyclical and structural conditions, while pull factors are relevant to economic, social and political conditions.Sekkat and Veganzones-Varoudakis (2007) have categorized the factors determining the FDI inflow into three groups: business or investment climate, trade \& economic factors and exchange market policies/ regulations.

\subsection{Outward FDI from China-A special case}

In case of China, government decisions play key role in FDI location choice by the firms. Traditional FDI theory is insufficient to explain the flow of FDI from developing countries particularly from China, thus required special attention. Firstly, most of the Chinese firms are State Owned Enterprises (SOEs), capital is available to them at below market rates leads to implication of imperfect market structure (Buckley et al., 2007; Lardy, 1998; Scott, 2002; Warner, Sek Hong, \& Xiaojun, 2004). Secondly, inappropriate and inefficient banking systems may make soft loans to potential outward investors (Antkiewicz \& Whalley, 2006; Child \& Rodrigues, 2005). Morck, Yeung, and Zhao (2008) explore in their study that the big four banks of China were responsible for 75 per cent of all commercial loans by the end of 2005, SOEs account for 73 per cent of short-term loans from 2001-04. These loans were available to SOEs because of preferential policies of government and lack of competency of the banks to assess the risks. Thirdly, conglomerate or business firms may operate an inefficient internal capital market that commendably subsidizes FDI (Liu, 2005). Fourthly, Institutional factors have also influence on Chinese OFDI. Government role and intervention in China's economy is large and affected greatly by China's polices and interests. Some of the OFDI decisions are more oriented around the political objectives rather than the pursuit of profit maximizing strategy (Kolstad \& Wiig, 2012). Chinese OFDI in Africa and Southeast Asia performed for strengthen the relationship between China and these countries (Deng, 2004). Lastly, firms owned by family mostly have access to cheap capital from family members (Erdener \& Shapiro, 2005; Fernández-Arias \& Hausmann, 2001; Tsai, 2004)

\subsection{South Asia as inward FDI Destination}

Sahoo (2006) in his study mentioned location advantages associated to South Asia in five groups " macro-economic fundamentals, infrastructural facilities, availability and cost of specific inputs, market size and growth prospects and FDI trade regulatory policies". Mottaleb and Kalirajan (2010) examined determinants of FDI inflows to 68 developing countries belonging to Asia, Africa and Latin America for the period 2005-2008, they found that beside GDP size, foreign aid international trade and business friendly environment are the most significant factors in determining FDI.Agiomirgianakis, Asteriou, and Papathoma (2003) carried a study for panel of OECD countries and found GDP per capita, real GDP growth, level of human capital, infrastructure, Trade openness are statistically significant and positively related to FDI.

Khan and Nawaz (2010) examined the determinants of FDI inflows to Pakistan for the period 1970-2004. They found that volume of exports, GDP growth rate, human population, tariff on imports and price index are major determinants of FDI inflow to Pakistan. Sahoo, Nataraj, and Dash (2014) in his work " foreign direct investment in South Asia: Policy, trends, impacts and determinants" pointed out that foreign direct investment in South Asia has enormously change since 1990-91 and more in recent years due to liberalization policies. Due to constant improvement in policies, South Asian economies have succeed in attracting FDI and have become important destination for FDI. However, there are still procedural interruptions and prohibition of FDI in certain industries. The strengthen of macroeconomic variables and political stability in the region are important factors to attract further FDI. Srinivasan (2011) conducted a detailed study for the period 1970-2007 to explore the FDI determinants in SAARC countries. His empirical results revealed that the market size, trade openness, GDP per capita, inflation, degree of risk and uncertainty, infrastructure facilities and SAARC countries formation are the most significant factors in determining FDI in the SAARC countries.

\subsection{Rationale for model's variable selection}

\subsubsection{FDI Stock}

FDI stock from Chinese firms is used as dependent variable rather FDI flows to the host South Asian economies, on the basis of previous studies suggesting stock variable is more precise measure of FDI locational distribution (Filippaios, Papanastassiou, \& Pearce, 2003; Kang \& Jiang, 2012). 


\subsubsection{Infrastructure (INFR)}

Infrastructural facilities like transportation, telecommunication, airports, internet access and water supply are important determinants of FDI. Infrastructural facilities and development has direct impact on minimizing cost of production and to encourage effective utilization of labor force (Wheeler \& Mody, 1992). Countries with good infrastructure facilities attract more foreign investments, therefore have positive impact on FDI inflow (Asiedu, 2006; Biswas, 2002; Cheng \& Kwan, 2000; Sahoo, 2006; Urata \& Kawai, 2000).

\subsubsection{Inflation (INF)}

Higher inflation rate indicates that the future purchasing power of money in the host economies may go down (depreciation of currency). Currency devaluation reduces the expected level of profitability for the MNEs, hence discourage FDI. inflation rate is volatile and unpredictable, creates uncertainty in setting the price and profitability rate to market-seeking MNEs, consequently discourage market-seeking FDI (Buckley et al., 2007).Moreover, they found that more Chinese OFDI flows to the countries with low inflation rate.

\subsubsection{Openness to FDI (OPEN)}

A country with more liberalize economic policies and strategies indicate conducive and convenient conditions for trade and investment (Chakrabarti, 2001).Openness to international investment is positively associated with FDI and significant factor in locational determinant of FDI (Buckley et al., 2007).

\subsubsection{GDP per capita Growth (GDPPG)}

The prospect of growth measured by GDP per capita has significant positive effect on FDI inflows. Countries with highly sustained growth pattern receive high FDI inflow than volatile economies. According to the market growth hypothesis, economies with more growing tendencies generate more opportunities for getting profits than those growing more sluggishly or not at all (Buckley et al., 2007). Overall GDP per capita growth has positive impact on FDI inflows in the host countries, which has been indicated in many research studies (Durham, 2004; Fan, Morck, Xu, \& Yeung, 2007; Saho0, 2006)

\subsubsection{Corruption $(C P)$}

Corruption and bad governance in a host country are associated with poor economic performance in the literature studies. It hampers and restrains the investment decisions by the firms in the host country. Corruption aggravates the cost of investment firms and reduced profits, consequently affects the FDI adversely (Egger \& Winner, 2006; Habib \& Zurawicki, 2002).Corruption in South Asia is acting as "grabbing hand", retard the economic growth by increasing transactional cost for the investing firms. The negative influence of corruption is widely proved in literature.

\subsubsection{Financial Development (FD)}

Financial development depicts access or availability of credit for investment in the host country. Financial development has significant impact on FDI decisions by MNEs as it affects the cost structure of investment projects (Al Nasser \& Garza, 2009). Kinda (2010) considered financial development is an engine of economic growth because it provides better business opportunities for customers and firms.

\subsubsection{Bilateral Trade (BT)}

Strong bilateral ties can have positive impact on FDI flow. Bilateral trade between China and host country also prove as significant factor in augmenting FDI flow. The variable of trade has been used widely in the literature for empirical investigation on FDI (Bevan \& Estrin, 2004; Buckley et al., 2007). This not only indicate the economic relationship between host and home country but also the intensity of transactional dealings and choice in terms of exporting destinations (Kang \& Jiang, 2012).

\subsubsection{Political Stability (POL)}

Institutional and political factors are important determinants of FDI, particularly for developing countries. In South Asia, at 
the country level, high political risks and obstacles have been an important deterrent of FDI inflows (Sahoo et al., 2014). Clarke and Logan (2008) in their study found that FDI flows are greatest to countries that have less political risk and better physical infrastructure. The high sunk cost of FDI is associated with uncertainties including the political uncertainty, makes investors highly sensitive in their investment decisions (J. Yu \& J. P. Walsh, 2010).

\subsubsection{Market Potential (MP)}

A country with large population may also proxy host country market potential. Mohamed and Sidiropoulos (2010) in their study for MENA countries found that market potential is significant and positively related with FDI as the region has large population size. South Asia, considering the big market size of population of 1.70 billion ( $24 \%$ of world population) may also be attractive destination for Chinese foreign investment firms.

\subsubsection{Trade Openness (TO)}

An Economy with more open policies for trade attracts the export-oriented FDI into the host country (UNCTAD, 2009). The conceptual hypothesis derived from the theories suggests that the benefits from trade are higher in export promotion regimes rather than import-led regimes. Openness to trade has been found positively associated with FDI inflow in host countries (Asiedu, 2002; Sahoo, 2006).

Table 2: The Determinants of China's OFDI.

\begin{tabular}{|c|c|c|c|}
\hline Variable & Proxy & Exp Sign & Source (s) \\
\hline China's FDI (FDI) & China's OFDI stock in South Asian countries & $\mathrm{n} / \mathrm{a}$ & $\begin{array}{l}\text { Statistical Bulletin of China's Outward Foreign Direct Investment, } \\
\text { UNCTAD }\end{array}$ \\
\hline \multirow{4}{*}{$\begin{array}{l}\text { Infrastructure (INFR) } \\
\text { Inflation (INF) } \\
\text { Openness to FDI (OPEN) } \\
\text { GDP per capita growth } \\
\text { (GDPPG) }\end{array}$} & Telephone lines (per 100 people) & + & World Bank Development Indicators \\
\hline & Consumer prices (annual \%) & $+/-$ & World Bank Development Indicators, UNCTAD \\
\hline & FDI net inflow (\% of GDP) & + & World Bank Development Indicators \\
\hline & Annual GDP per capita growth & + & World Bank Development Indicators \\
\hline Corruption $(\mathrm{CP})$ & Level of corruption & - & $\begin{array}{l}\text { Worldwide Governance Indicators (WGI) index has been changed } \\
\text { from }(-2.5 \text { to } 2.5) \text { to }(0-10) \text { for model estimation. }\end{array}$ \\
\hline Financial Development (FD) & $\begin{array}{l}\text { Domestic credit to private sector by banks (\% } \\
\text { of GDP) }\end{array}$ & + & World Bank Development Indicators \\
\hline Bilateral Trade (BT) & $\begin{array}{l}\text { Annual volume of bilateral trade (export and } \\
\text { import) }\end{array}$ & + & China Statistical Year books, UNCTAD \\
\hline Political stability (POL) & Political stability/no violence & - & $\begin{array}{l}\text { Worldwide Governance Indicators (WGI) index has been changed } \\
\text { from }(-2.5 \text { to } 2.5) \text { to }(0-10) \text { for model estimation. }\end{array}$ \\
\hline Marke & Popt & + & World Bank Development Indicators \\
\hline Trade Openness (TO) & Trade (\% of GDP) & + & World Bank Development Indicators \\
\hline
\end{tabular}

\section{Model and Data}

According to previous discussion, the following model is constructed. $\operatorname{lnOFDI}=a+\beta_{1} \ln \left|\mathrm{NFR}+\beta_{2} \ln \right| \mathrm{NF}+\beta_{3} \operatorname{lnOPEN}+\beta_{4} \operatorname{lnGDPPG}+\beta_{5} \ln \mathrm{nCP}+\beta_{6} \ln F D+\beta_{7} \ln B T+\beta_{8} \ln \mathrm{POL}+\beta_{9} \operatorname{lnMP}+$ $\beta_{10} \ln T O+\varepsilon i t$

Table 2 shows the proxies used for variables, expected sign of variables and data source(s). Our dependent variable is China's annual stock of FDI in a host country. In our panel data set, five South Asian countries (Bangladesh, India, Nepal, Pakistan and Sri Lanka) are host to China's outward FDI as the data for the rest of three South Asian countries (Afghanistan, Bhutan, Maldives) is not available or insufficient for analysis.

The choice of time period 2003-2012 is useful and justified for analysis. Firstly, "Statistical Bulletin of China's Outward Foreign Direct Investment" is mutually issued by National Bureau of Statistics, Ministry of Commerce and the Administration of Foreign Exchange of People's Republic of China since 2003. Secondly, China's OFDI rapidly increase since 2003 and such trend continues till the year, 2012, therefore, the analysis of China's OFDI is meaningful for these years.

The data contains few entities and few time periods, so there is little variation over the time in independent variables included in the model for panel analysis. Therefore, we are using linear estimation methods (Random Effects $(\mathrm{RE})$, Fixed Effects (FE) and Pooled OLS). Pooled OLS assumes homogeneity for all countries, while the FE method introduces the country specific effect by estimating different intercepts for each pool member country. RE method, which is based on Generalized Least Squares (GLS) estimator takes time series as well as the cross-sectional dimensions of the data into account, treats intercepts as random variables across the pooled member countries. 
The choice and reliability of method for panel estimation lies on the tests conducted. Hausman test with P-value= $0.243>0.05$ shows Random Effects model is better than Fixed Effects model, suggesting that individual effects are uncorrelated with the regressors. Breusch-Pagan Lagrange Multiplier (LM) test is conducted for the choice between Random effects model and Pooled OLS. LM test provides P-value $=0.125>0.05$, shows Pooled OLS is better choice compare to Random effects, merely because of no individual effects.

In order to obtain an efficient OLS, some basic assumptions must be satisfied by conducting several tests after the regression. Shapiro-Wilk W test is designed to examine the normal distribution of residuals. To identify the problem of multicollinearity, autocorrelation and homoskedasticity, specific tests namely Variance Inflation Factor (VIF), Wooldridge test and the Bruesch-Pagan test has been carried out respectively. The Interpretation and implication of the tests is discussed in the forthcoming section.

\section{Methodology and Regression Results}

Table 3 shows the results when equation (1) is estimated using POLS method after conducting Hausman specification and LM tests. Before proceeding to the main regression results, the interpretation of the diagnostic tests results (Table 4) is discussed first. Breusch-Pagan test with P-value (0.512) greater than five per cent reveals that variance of residual is constant or it is homogenous. The residuals of the model are normally distributed as the probability value $(0.057)$ in Shapiro-Wilk W test is greater than five percent. Wooldridge test with probability value $(0.239)>0.05$ proves that there is no serial autocorrelation in the model.

Table 3: Results for the determinants of Chinese FDI and VIF test

\begin{tabular}{|c|c|c|c|}
\hline Variables & POLS & VIF & Tolerance \\
\hline Infrastructure & $\begin{array}{c}0.944^{\star \star \star} \\
(0.140)\end{array}$ & 2.01 & 0.498 \\
\hline Inflation & $\begin{array}{l}0.779^{*} \\
(0.401)\end{array}$ & 2.03 & 0.493 \\
\hline Openness to FDI & $\begin{array}{l}-0.085 \\
(0.151)\end{array}$ & 2.41 & 0.414 \\
\hline GDP per capita growth & $\begin{array}{l}-0.460 \\
(0.352)\end{array}$ & 2.61 & 0.384 \\
\hline Corruption & $\begin{array}{c}-4.110^{\star \star \star} \\
(0.762)\end{array}$ & 2.28 & 0.438 \\
\hline Financial Development & $\begin{array}{l}-0.656 \\
(0.629)\end{array}$ & 2.86 & 0.349 \\
\hline Bilateral Trade & $\begin{array}{c}0.627^{\star \star \star} \\
(0.126)\end{array}$ & 3.15 & 0.317 \\
\hline Political stability & $\begin{array}{l}-0.160 \\
(0.275)\end{array}$ & 4.76 & 0.210 \\
\hline Market potential & $\begin{array}{l}2.533^{* *} \\
(1.008)\end{array}$ & 3.44 & 0.290 \\
\hline Trade Openness & $\begin{array}{l}2.97^{\star \star} \\
(0.905)\end{array}$ & 4.16 & 0.240 \\
\hline Const & $\begin{array}{c}-7.798^{\star *} \\
(3.793)\end{array}$ & - & - \\
\hline Hausman Test & & \multirow{7}{*}{\multicolumn{2}{|c|}{$\begin{array}{c}(p-\text { value }=0.243) \\
(p \text {-value }=0.125) \\
(p-v a l u e=0.512) \\
(p-\text { value }=0.057) \\
(p-\text { value }=0.239) \\
0.84 \\
46\end{array}$}} \\
\hline Lagrangian multiplier test & & & \\
\hline Breusch-Pagan/Cook-Weisberg test & & & \\
\hline Shapiro-Wilk W test & & & \\
\hline Wooldridge test & & & \\
\hline Adjusted R-squared & & & \\
\hline N & & & \\
\hline
\end{tabular}

Source: Author's own calculations.

Table 4 present the correlation matrix results between China's outward FDI and all variables used in the model, while variance inflation factor (VIF) results are presented in table 3. These results indicate that data in overall model is adequate for estimation purpose. 
Table 3 (column 2) represent main results for POLS from our regression. We find that the relationship between Infrastructure variable and China's FDI is positive and significant at 1 per cent level. Kinoshita and Campos (2003) in their work pointed out existence of good infrastructure is an essential condition for successful operations by foreign investors regardless of the type of FDI. South Asian economies, therefore, by improving infrastructural facilities can attract more FDI from China. Sahoo et al. (2014) \& Srinivasan (2011) in their studies also found similar positive relationship between infrastructural development and FDI for South Asian countries. Inflation coefficient (LINF) is significant and positively associated with FDI, indicating that 1 percent increase in the inflation results rise in Chinese FDI by $0.78 \%$. This result is in parallel with work of Buckley et al. (2007), mentioned that Chinese investors are attracted by moderate demand inflation and the positive association between the variables is supported on the argument that moderate demand inflation complements economic growth.

The corruption variable is highly significant and correctly signed, indicating that $1 \%$ increase in the variable associated with 4.11\% decrease in Chinese FDI. Our result is consistent with recent study conducted by Quazi (2014) for East \& South Asian economies. The larger value of corruption coefficient indicates that quality of institution matters a lot for making FDI inflow in South Asia. The existence of good institutions in developing countries is important determinant of FDI, as quality institutions are positively associated with economic growth (Sahoo et al., 2014; J. Yu \& M. J. P. Walsh, 2010).

As expected, the coefficient on the bilateral trade is positive and highly significant. A $1 \%$ increase in bilateral trade is associated with $0.627 \%$ increase in Chinese FDI to South Asian countries. This indicates that the recent surge in bilateral trade ties between China and South Asia has significant positive impact on mindset of Chines investing firms i.e. good trade relationship between the countries have augmented impact on FDI. Bilateral trade between China and host South Asian countries is dominated by China's export, which supports the conventional argument that FDI follows export. This tendency also supports the market seeking motivation of Chinese firms in South Asian region. Market potential proxy by population growth rate has expected positive effect on Chinese OFDI and highly statistically significant. A $1 \%$ rise in the variable increase Chinese OFDI by $2.53 \%$, indicating that potential market growth of South Asian economies attracts Chinese investment firms. South Asia having large market size and consumption oriented nature, is attractive for investment opportunities even its present purchasing power is low.

Trade Openness as expected correctly signed and positively associated with FDI, with a $1 \%$ increase in the variable rising Chinese FDI by $2.97 \%$. This shows that trade openness is extremely important determinant of Chinese FDI flow to South Asia. Trade liberalization policy initiated in 1990's in major South Asia countries continue to be more liberalized, therefore, attracting FDI in the region. Tariff rates have been reduced considerably over the years. Export oriented policies opens up the economy, hence benefits the economies by attracting FDI (Singh \& Jun, 1995).

The coefficient of openness to FDI (LOPEN), financial development (LFD), GDP per capita growth (LGDPPG) and political stability (LPOL) are negatively associated with FDI but all these variables are insignificant in our model. Chinese investment firms have unique characteristics and multiple motivations, hence its negative relationship with Openness to FDI can be expected. The opposite association between financial depth and FDI shows that higher level of credit is available to private sector which indicates that foreign capital in the shape of FDI may not be required. J. Yu and J. P. Walsh (2010) in their study also found similar negative relationship between the variables. The negative relationship of GDPPG with Chinese FDI could be due to balancing of the market potential effect with the production cost effect, which must work in the opposite directions. Political stability is negatively related with Chinese FDI but insignificant in our model. This negative association is quite consistent with existing literature particularly for developing countries with weak institutional environment (e.g. Buckley et al., 2007).

Table 4: Correlation matrix

\begin{tabular}{lccccccccccc}
\hline & LFDI & LINFR & LINF & LOPEN & LGDPPG & LCP & LFD & LBT & LPOL & LMP & LTO \\
\hline LFDI & 1.000 & & & & & & & & & & \\
LINFR & 0.630 & 1.000 & & & & & & & & \\
LINF & 0.335 & 0.229 & 1.000 & & & & & & & \\
LOPEN & 0.413 & 0.319 & 0.085 & 1.000 & & & & & & & \\
LGDPPG & -0.173 & 0.024 & -0.084 & 0.332 & 1.000 & & & & & & \\
LCP & -0.194 & 0.368 & -0.002 & 0.099 & 0.224 & 1.000 & & & & & \\
LFD & -0.088 & 0.057 & 0.157 & -0.041 & 0.385 & 0.095 & 1.000 & & & & \\
LBT & 0.663 & 0.428 & 0.007 & 0.587 & 0.270 & -0.013 & 0.210 & 1.000 & & & \\
LPOL & -0.448 & -0.141 & -0.276 & 0.144 & 0.683 & 0.272 & 0.552 & -0.037 & 1.000 & & \\
LMP & 0.188 & -0.149 & -0.332 & 0.018 & -0.385 & -0.257 & -0.470 & 0.160 & -0.429 & 1.000 & \\
LTO & -0.180 & 0.089 & 0.295 & 0.137 & 0.340 & 0.562 & 0.284 & -0.179 & 0.437 & -0.722 & 1.000 \\
\hline
\end{tabular}




\section{Conclusion and Policy implications}

This study explores the magnitude, pattern and determinants of Chinese FDI in selected South Asian economies over the period 2003-2012. The present study employed POLS method for the empirical investigation of the model after conducting Hausman specification and LM tests. We have used economic variables along with institutional variables in this empirical study to determine Chinese FDI in South Asia. The results of the study revealed that infrastructural facilities, inflation, level of corruption, bilateral trade, market potential and trade openness are statistically significant determinants of FDI inflows in South Asian countries. Market potential and openness to trade to a large extent as evident by the size of their respective coefficients, have significant positive influence while corruption variable play highly negative role in attracting Chinese FDI.

The findings of this study have some policy implications for policy makers to attract further FDI inflows. The empirical results suggest that in order to attract Chinese FDI, South Asian economies should step forward and opt incremental efforts to remove all trade barriers, reduce corruption and build appropriate institutions. Policies and Economic strategies should aim at liberalizing trade structure, reducing macroeconomic instability and provision of better infrastructural facilities to attract further Chinese FDI in South Asia.

In this empirical study, we are not able to examine the influence of some variables that would have influenced Chinese FDI inflows due to data limitation, thus required further research work to fill this gap.

\section{References}

Agiomirgianakis, G. M., Asteriou, D., \& Papathoma, K. (2003). The determinants of foreign direct investment: A panel data study for the OECD countries, (Report No. 03/06). London, UK: Departmentof Economics, City University London.

Al Nasser, O., \& Garza, X. (2009). Do well-functioning financial systems affect the FDI flows to Latin America. International Research Journal of Finance and Economics, 29, 60-75.

Amighini, A., Rabellotti, R., \& Sanfilippo, M. (2011). China's outward FDI: An industry-level analysis of host country determinants: CESifo working paper: Empirical and Theoretical Methods.

Antkiewicz, A., \& Whalley, J. (2006). Recent Chinese buyout activity and the implications for global architecture: National Bureau of Economic Research.

Asiedu, E. (2002). On the determinants of foreign direct investment to developing countries: is Africa different? World development, 30(1), 107-119.

Asiedu, E. (2006). Foreign direct investment in Africa: The role of natural resources, market size, government policy, institutions and political instability. The World Economy, 29(1), 63-77.

Aykut, D., \& Goldstein, A. (2007). Developing country multinationals: South-South investment comes of age. Industrial Development for the 21st Century: Sustainable Development Perspectives, New York, 85-116.

Bevan, A. A., \& Estrin, S. (2004). The determinants of foreign direct investment into European transition economies. Journal of comparative economics, 32(4), 775-787.

Biswas, R. (2002). Determinants of foreign direct investment. Review of Development Economics, 6(3), $492-504$.

Brautigam, D. (2009). The dragon's gift: the real story of China in Africa: Oxford University Press.

Buckley, P. J., Clegg, L. J., Cross, A. R., Liu, X., Voss, H., \& Zheng, P. (2007). The determinants of Chinese outward foreign direct investment. Journal of international business studies, 38(4), 499-518.

Calvo, G. A., Leiderman, L., \& Reinhart, C. M. (1996). Inflows of Capital to Developing Countries in the 1990s. The Journal of Economic Perspectives, 123-139.

Chakrabarti, A. (2001). The determinants of foreign direct investments: Sensitivity analyses of cross-country regressions. Kyklos, 54(1), 89114.

Cheng, L. K., \& Kwan, Y. K. (2000). What are the determinants of the location of foreign direct investment? The Chinese experience. Journal of international economics, 51(2), 379-400.

Cheung, Y. W., \& Qian, X. (2009). Empirics of China's outward direct investment. Pacific Economic Review, 14(3), 312-341.

Child, J., \& Rodrigues, S. B. (2005). The Internationalization of Chinese Firms: A Case for Theoretical Extension?[1]. Management and organization review, 1(3), 381-410.

Clarke, R., \& Logan, T.-M. L. (2008). EMERGING FDI PATTERNS IN THE CARICOM REGION. International Journal of Business Research, $8(1)$

Deng, P. (2004). Outward investment by Chinese MNCs: Motivations and implications. Business Horizons, 47(3), 8-16.

Dunning, J. H. (1976). Trade, location of economic activity and the MNE: A search for an eclectic approach: University of Reading, Department of Economics.

Durham, J. B. (2004). Absorptive capacity and the effects of foreign direct investment and equity foreign portfolio investment on economic growth. European economic review, 48(2), 285-306.

Egger, P., \& Winner, H. (2006). How corruption influences foreign direct investment: a panel data study. Economic Development and Cultural Change, 54(2), 459-486. 
Erdener, C., \& Shapiro, D. M. (2005). The internationalization of Chinese family enterprises and Dunning's eclectic MNE paradigm. Management and organization review, 1(3), 411-436.

Fan, J. P., Morck, R., Xu, L. C., \& Yeung, B. (2007). „Does "Good Government” Draw Foreign Capital. Explaining China" s Exceptional Foreign Direct Investment Inflow", Washington DC: World Bank Policy Research Working Paper, 4206.

Fedderke, J. W., \& Romm, A. T. (2006). Growth impact and determinants of foreign direct investment into South Africa, 1956-2003. Economic Modelling, 23(5), 738-760.

Fernandez-Arias, E. (1996). The new wave of private capital inflows: push or pull? Journal of Development Economics, 48(2), 389-418.

Fernández-Arias, E., \& Hausmann, R. (2001). Is foreign direct investment a safer form of financing? Emerging Markets Review, 2(1), $34-49$.

Fernandez-Arias, E., \& Montiel, P. J. (1996). The surge in capital inflows to developing countries: an analytical overview. The World Bank Economic Review, 10(1), 51-77.

Filippaios, F., Papanastassiou, M., \& Pearce, R. (2003). The evolution of US outward foreign direct investment in the Pacific Rim: A crosstime and country analysis. Applied Economics, 35(16), 1779-1787.

Gottschalk, R. (2001). Lenders and investors' international portfolio allocation decisions: what do we know. Institute of Development Studies: Sussex.

Habib, M., \& Zurawicki, L. (2002). Corruption and foreign direct investment. Journal of international business studies, 291-307.

Kang, Y., \& Jiang, F. (2012). FDI location choice of Chinese multinationals in East and Southeast Asia: Traditional economic factors and institutional perspective. Journal of World Business, 47(1), 45-53.

Khan, R. E. A., \& Nawaz, M. A. (2010). Economic Determinants of Foreign Direct Investment in Pakistan. J Economics, 1(2), 99-104.

Kinda, T. (2010). Investment climate and FDI in developing countries: firm-level evidence. World development, 38(4), 498-513.

Kinoshita, Y., \& Campos, N. F. (2003). Why does FDI go where it goes? New evidence from the transition economies: International Monetary Fund.

Kolstad, I., \& Wiig, A. (2012). What determines Chinese outward FDI? Journal of World Business, 47(1), $26-34$.

Lardy, N. R. (1998). China's unfinished economic revolution: Brookings Institution Press.

Lecraw, D. J. (1993). Outward direct investment by Indonesian firms: motivation and effects. Journal of international business studies, 589600.

Liu, L. (2005). China's Industrial Policies and the Global Business Revolution: Routledge.

Mateev, M. (2009). Determinants of Foreign Direct Investment in Central and Southeastern Europe: New Empirical Tests. Oxford Journal, $8(1)$.

Mohamed, S. E., \& Sidiropoulos, M. G. (2010). Another look at the determinants of foreign direct investment in MENA countries: an empirical investigation. Journal of Economic Development, 35(2), 75-95.

Morck, R., Yeung, B., \& Zhao, M. (2008). Perspectives on China's outward foreign direct investment. Journal of international business studies, 39(3), 337-350.

Mottaleb, K. A., \& Kalirajan, K. (2010). Determinants of foreign direct investment in developing countries a comparative analysis. Margin: The Journal of Applied Economic Research, 4(4), 369-404.

Quazi, R. M. (2014). Corruption and Foreign Direct Investment in East Asia and South Asia: An Econometric Study. International Journal of Economics \& Financial Issues (IJEFI), 4(2).

Sahoo, P. (2006). FDI in South Asia: trends, policy, impact and determinants. Asian Development Bank Institute discussion paper series(56).

Sahoo, P., Nataraj, G., \& Dash, R. K. (2014). Foreign Direct Investment in South Asia: Policy, Impact, Determinants and Challenges: New Delhi: Springer India.

Scott, W. R. (2002). The changing world of Chinese enterprise: An institutional perspective The management of enterprises in the People's Republic of China (pp. 59-78): Springer.

Sekkat, K., \& Veganzones-Varoudakis, M. A. (2007). Openness, investment climate, and fdi in developing countries. Review of Development Economics, 11(4), 607-620.

Singh, H., \& Jun, K. (1995). Some new evidence on determinants of foreign direct investment in developing countries. World Bank Policy Research Working Paper(1531).

Srinivasan, P. (2011). Determinants of Foreign Direct Investment in SAARC Nations: An Econometric Investigation. IUP Journal of Managerial Economics, 9(3).

Tsai, K. S. (2004). Back-alley banking: Private entrepreneurs in China: Cornell University Press.

UNCTAD. (2013). World Investment Report.

Urata, S., \& Kawai, H. (2000). The determinants of the location of foreign direct investment by Japanese small and medium-sized enterprises. Small Business Economics, 15(2), 79-103.

Warner, M., Sek Hong, N., \& Xiaojun, X. (2004). 'Late development'experience and the evolution of transnational firms in the People's Republic of China. Asia Pacific Business Review, 10(3-4), 324-345.

Wheeler, D., \& Mody, A. (1992). International investment location decisions: The case of US firms. Journal of international economics, 33(1), 57-76.

World Bank Group Report (2013).Trends and determinants of foreign direct investment in South Asia, Report No. ACS 4862.

Yu, J., \& Walsh, J. P. (2010). Determinants of Foreign Direct Investment: A Sectoral and Institutional Approach: International Monetary Fund.

Yu, J., \& Walsh, M. J. P. (2010). Determinants of Foreign Direct Investment: A Sectoral and Institutional Approach (EPub): International Monetary Fund.

Zhang, X., \& Daly, K. (2011). The determinants of China's outward foreign direct investment. Emerging Markets Review, 12(4), 389-398. 